\title{
Anti-Oxidant Activity of Carica Papaya Seed Extracts on Indomethacin-Induced Ulcer in Rats
}

\author{
Gadzama P. A ${ }^{1}$, Wurochekke A. $\mathbf{U}^{2}$, Mahmoud, S. J. ${ }^{3}$ \\ ${ }^{1}$ Laboratory Sevices Department, Federal Medical Centre, P.M.B 2017, Lamido Zubairu Way, Yola by-pass, Adamawa State, Nigeria. \\ ${ }^{2,3}$ Department of Biochemistry, Modibbo Adama University of Technology, P.M.B 2076 Yola, Adamawa State,Nigeria
}

\begin{abstract}
The seed of Carica papaya has been traditionally used for the treatment of peptic ulcer disease and other ailments. The Antioxidant Activity of Carica papaya seed Extracts on Indomethacin-induced Ulcer in Rat was investigated to validate this claim. The qualitative phytochemical screening of the aqueous Carica papaya seed extract showed the presence of tanins, saponins, flavonoids, alkaloids, phenols, terpenoids, cardiac glycosides, anthraquinones and steroids. Quantitatively, Phenols and flavonoids (20.80\% and $20.40 \%)$ were found to be the highest in the phytochemicals while anthraquinones and saponins $(5.80 \%$ and $6.40 \%)$ were the least in content. The study was conducted on fifty-five (55) young albino rats weighing between 120-150g were grouped into eleven (11) of five (5) each. Peptic ulcer was induced in all the rats using indomethacin at $50 \mathrm{mg} / \mathrm{kg} / \mathrm{bw}$ single dose and the level of total endogenous antioxidants were significantly $(p>0.05)$ reduced when normal groups $(73.30 \pm 0.92)$ was compared with the induced group (27.42 \pm 0.85$)$. The rats were treated with varied concentrations of both aqueous and ethanolic seed extracts at 100, 150, 300 and 450mg/kg/bw. Oral administration of aqueous extract $(100 \mathrm{mg} / \mathrm{kg} / \mathrm{bw})$ of the seed significantly $(p>0.05)$ increased the total anti-oxidant levels to $(86.28 \pm$ 3.82 ) in the treated animals. Treatment was able to prevent reduction in the levels of anti-oxidant caused by indomethacin. Treatment using the extract also significantly ( $p>0.05)$ boosted total protein concentration level $(80.08 \pm 0.80)$ when compared to the negative control (56.94 \pm 3.29$)$. This study showed anti-ulcer activity of Carica papaya seed extracts by improving the anti-oxidant activity.
\end{abstract}

Keywords: Anti-oxidant Activity, Anti-ulcer effect, Carica papaya, Albino rats, Indomethacin. Aqueous Extract (AE), Ethanolic Extract (EE)

\section{Introduction}

An ulcer is basically an inflammed break in the skin or in the mucus membrane lining the gastrointestinal tract (Fong and Devlin, 2008). Peptic ulcer, also known as peptic ulcer disease (PUD), is defined as a breach in the lining (mucosa) of the digestive tract produced by digestion of the mucosa by pepsin and acid basically as a result of the disturbance of the normal equilibrium caused by either enhanced aggression or diminished mucosal resistance (Grossman, 2009). The peptic areas of the human body under normal circumstances are the stomach and duodenum. Therefore, a common medical disorder with the peptic areas of the body is peptic ulcer disease. Gastrinomas (Zollinger Ellison syndrome), a rare gastrin-secreting tumours, also cause multiple and difficultto-heal ulcers (Greenstein and Greenstein, 2007).

The prevalence of PUD is kept at maximum of $40 \%$ in developed countries, but it is higher in developing countries being estimated at $70 \%$ of the population. Generally, the impressive fall in its incidence is as a result of the development of new effective medication and acid suppresants, as well the discovery of the causative agent, $H$. Pylori (Wolfe et al., 1999). Similarly, Peptic ulcer disease (PUD) has a tremendous effect on morbidity and mortality, and the lifetime risk for developing the disease is approximately 10\% (Jyotheeswaran et al., 1998).

People who regularly take Non-Steroidal Anti-inflammatory Drugs (NSAIDs) - such as those with chronic conditions like arthritis - are five times more likely to develop peptic ulcers than people who do not take those (Huang et al., 2002). Similarly, even occasional users of NSAIDs - of any age - can develop a peptic ulcer disease, since they tend to inhibit the formation of prostaglandins thereby leading to gastric bleeding and erosion.

But infection of the stomach mucosa with Helicobacter pylori is now generally considered to be a major cause, especially of duodenal ulcer (Huang et al., 2002).

Free radicals are capable of attacking the healthy cells of the body which may lead to damage, disease and severe disorders. Free radicals have been implicated in the pathogenesis of many diseases which include peptic ulcer disease. Therefore, free radical formation is controlled naturally by various beneficial compounds known as antioxidants

Carica papaya seeds have recently attracted attention as a potential health food, while much of the evidence supporting this notion is unverified. The papaya seeds are nontoxic and might be treated as supplement or eating them whole, or the seeds could be grinded and used as pepper since they taste fairly similar (Aravind, 2013). Several medicinal plants including Carica papaya have been reported to possess antiulcerogenic activity by virtue of their predominant effect on mucosal defensive factors. These plants are used to treat different gastrointestinal illnesses, including peptic ulcer disease (Aravind, 2013). Here in this study, we present the antioxidant activity of Carica papaya seed extract as one of the indices for the treatment of peptic ulcer disease.

\section{Materials and Methods}

\section{Plant Material}

Pawpaw seeds from riped pawpaw (Carica papaya) fruits was obtained from Asma'u Farms, along Gombi Road, Jimeta. The seeds were inspected and identified in the 


\section{International Journal of Science and Research (IJSR) \\ ISSN (Online): 2319-7064 \\ Index Copernicus Value (2013): 6.14 | Impact Factor (2014): 5.611}

Department of Plant Science, Modibbo Adama University of Technology; Yola, Nigeria. Debris and other pawpaw dirts were washed off the choosen seeds with clean water. And the seeds was allowed to first drain and evenly spread out on clean papers, and put under shade to allow proper drying.

\section{Experimental Animals}

Fifty-five albino rats, weighing $150 \pm 5 \mathrm{~kg}$ were procured from National Veterinary Research Institute, Vom-Jos, Plateau State, Nigeria. The animals were fed on standard rat pellet made (by Pfizer feeds, Jos) and clean water ad-libitum for 7 days before experiment was done on them.

\section{Drugs}

Anti-ulcer agent Omecid (Omeprazole) was obtained in the form of Capsules from Saga Laboratories Survey No. 198/2 \& 198/3 ChachrawadiVasna, Ta,: Sanand, Dist,: Ahmedabad-382 210 INDIA.

\section{Methods}

Preparation of Ethanolic Extract

The ethanolic extraction of the carica papaya seeds was done using $70 \%$ ethanol according to the method of Mogana et al (2011). About 500g of the pulverised carica papaya seed extracts was mixed and shaken well in $70 \%$ ethanol at $4^{\circ} \mathrm{C}$ and kept for $24 \mathrm{hrs}$ with intermittent shaking. The mixture was then separated using Whatman filter paper No.1 and finally evaporated to dryness at $50^{\circ} \mathrm{C}$ in hot air oven. The dried extracts obtained was kept in a clean dried container and appropriately labelled. The extracts was appropriately reconstituted in distilled water in the course of the experiment.

\section{Experimental Design}

A total number of Fifty-five albino rats weighing 120-150g were used for the experiment. All animals were fed on normal rat diet and water ad-libitum, and were caged under healthy conditions of humidity, temperature $\left(20-25^{\circ} \mathrm{C}\right)$ and light ( $12 \mathrm{hr}$-light: $12 \mathrm{hr}$-dark cycle) for fourteen days to acclimatise before the on-set of the experiment. Rats were divided into eleven groups of equal weights and number ( 5 rats per each group). Group (1) kept as positve control group, Group (2) kept as negative control group and Group (3) served as Standard Drug control group. These groups were all fed on normal rat diets but Group (2) and (3) had ulcer induced with indomethacin, $50 \mathrm{mg} / \mathrm{kg} / \mathrm{bw}$ (Magistreni et al., 1988). Group (2) had no treatment while Group (3) had treatment with Standard Drug (Omeprazole, $20 \mathrm{mg} / \mathrm{kg} / \mathrm{bw})$. The first and second groups of $(4,5,6$ and 7$)$ had normal diets, ulcer induced and treated orally with (100, 150,300 and $450 \mathrm{mg} / \mathrm{kg} / \mathrm{bw}$ ) by tubing of both Aqueous and Ethanolic extracts of Carica papaya seed. All experiment lasted for fourteen days.

At the end of the experiment, all rats were fasted for $12 \mathrm{hrs}$ and their blood were collected into heparinised containers through cardiac puncture.

\section{Ethical Consideration}

The experimental protocol was adhered to minimise adverse effects on each experimental animal. The experiments was carried out under supervision and experiments were conformed to the guidelines and ethics on Animal Care and Research.

\section{Statistical Analysis}

The data obtained were expressed as the Mean \pm Standard Error of Mean (SEM). And the data were also analysed using the Student's t-test and the Analysis of Variance (ANOVA).

\section{Results}

Table 1. shows qualitative phytochemical components of the aqueous seed extract of the Carica papaya plant was determined. The phytochemicals that were qualitatively present in the aqueous extract included: saponins, tannins, phenols, alkaloids, flavonoids, terpenoids, anthraquinones, cardiac glycosides and steroids.

Table 1: Qualitative phytochemical Analysis of Aqueous Extract of Carica papaya seed

\begin{tabular}{|c|c|}
\hline Phytochemical & Inference \\
\hline Saponins & + \\
\hline Tannins & + \\
\hline Phenols & + \\
\hline Alkaloids & + \\
\hline Terpenoids & + \\
\hline Anthraquinones & + \\
\hline Cardiac Glycosides & + \\
\hline Steroids & + \\
\hline
\end{tabular}

Keys: $+=$ Present, $-=$ Absent .

Table 2. indicated the quantitative phytochemicals estimated in the aqueous seed extract of Carica papaya. The phytochemicals showed phenols and flavonoids to have the highest percentage of 20.80 and $20.40 \%$ respectively, while saponins and anthraquinones have the lowest percent constituent as 6.40 and $5.80 \%$.

Table 2: The Quantitative determination of phytochemical components of Aqueous Extract of Carica papaya seed

\begin{tabular}{|l|l|l|}
\hline Constituents & Concentrations (mg) & Percentage (\%) \\
\hline Saponins & $0.31 \pm 0.01$ & 6.40 \\
\hline Tannins & $0.47 \pm 0.01$ & 9.40 \\
\hline Phenols & $1.04 \pm 0.01$ & 20.80 \\
\hline Alkaloids & $0.63 \pm 0.01$ & 12.60 \\
\hline Flavonoids & $1.02 \pm 0.01$ & 20.40 \\
\hline Terpenoids & $0.46 \pm 0.01$ & 9.20 \\
\hline Anthraquinones & $0.31 \pm 0.00$ & 5.80 \\
\hline Glycosides & $0.94 \pm 0.01$ & 18.60 \\
\hline Steroids & $0.48 \pm 0.01$ & 9.60 \\
\hline
\end{tabular}

Results are expressed as mean $\pm \operatorname{SEM}(n=5)$ and Percentage (\%).

The results of Table 3, showed significant difference between Group 2 and Group 1 in both extracts. While aqueous exract has shown more activity $(p>0.05)$ than ethanolic extract. 


\section{International Journal of Science and Research (IJSR) ISSN (Online): 2319-7064 \\ Index Copernicus Value (2013): 6.14 | Impact Factor (2014): 5.611}

Table 3: Total Antioxidant Activity of Aqueous and Ethanolic Extracts of Carica papaya seed using DPPH

\begin{tabular}{|c|c|c|}
\hline Treatment & $\begin{array}{c}\text { Concentration } \\
(\%) \text { AE }\end{array}$ & $\begin{array}{c}\text { Concentration } \\
(\%) \text { EE }\end{array}$ \\
\hline Group 1: Normal Control & $73.30 \pm 0.92$ & $73.30 \pm 0.92$ \\
\hline Group 2: Negative Control & $27.42 \pm 0.85^{*}$ & $27.42 \pm 0.85^{*}$ \\
\hline $\begin{array}{c}\text { Group 3: Standard Drug } \\
\text { (Omeprazole, } 20 \mathrm{mg} / \mathrm{kg} / \mathrm{bw})\end{array}$ & $42.58 \pm 0.31^{\mathrm{a}}$ & $42.58 \pm 0.31^{\mathrm{a}}$ \\
\hline Group 4: $100 \mathrm{mg} / \mathrm{kg} / \mathrm{bw}$ & $86.28 \pm 3.82^{\mathrm{ab}}$ & $30.52 \pm 1.95$ \\
\hline Group 5: $150 \mathrm{mg} / \mathrm{kg} / \mathrm{bw}$ & $67.48 \pm 2.85^{\mathrm{ab}}$ & $15.94 \pm 0.33$ \\
\hline Group 6: $300 \mathrm{mg} / \mathrm{kg} / \mathrm{bw}$ & $63.94 \pm 1.14^{\mathrm{ab}}$ & $10.54 \pm 0.20$ \\
\hline Group 7: $450 \mathrm{mg} / \mathrm{kg} / \mathrm{bw}$ & $43.7 \pm 2.93$ & $35.28 \pm 0.34$ \\
\hline
\end{tabular}

Results are expressed as mean \pm SEM $(n=5)$. "significant decrease than group 1; ${ }^{a}$ significant increase than group 2; ${ }^{\mathbf{a b}}$ significant increase than group 3; $\mathrm{AE}=$ Aqueous Extract of Carica papaya seed; $\mathrm{EE}=$ Ethanolic Extract of Carica papaya seed; SEM = Standard Error of Mean; $\mathrm{mg} / \mathrm{kg} / \mathrm{bw}=$ Milligram/Kilogram/Body weight; DPPH = (2,2-diphenyl-1picryl hydrazyl).

In Table 4, there is generally no significant difference in effect between the extracts and the Standard drug.

Table 4: The Total Antioxidant Activity of Aqueous and Ethanolic Extracts of Carica papaya Seed using TBARS Assay

\begin{tabular}{|l|c|c|}
\hline \multicolumn{1}{|c|}{ Treatment } & $\begin{array}{c}\text { Concentration } \\
\text { (\%) AE }\end{array}$ & $\begin{array}{c}\text { Concentration } \\
\text { (\%) } \text { EE }\end{array}$ \\
\hline Group 1: Normal Control & $91.35 \pm 0.95$ & $91.35 \pm 0.95$ \\
\hline Group 2: Negative Control & $67.84 \pm 0.74 *$ & $67.84 \pm 0.74$ \\
\hline Group 3: Drug Control & $77.54 \pm 0.52$ & $77.54 \pm 0.52$ \\
\hline Group 4: $100 \mathrm{mg} / \mathrm{kg} / \mathrm{bw}$ & $73.82 \pm 0.44$ & $71.12 \pm 0.60$ \\
\hline Group 5: $150 \mathrm{mg} / \mathrm{kg} / \mathrm{bw}$ & $64.10 \pm 6.89$ & $79.40 \pm 1.38$ \\
\hline Group 6: $300 \mathrm{mg} / \mathrm{kg} / \mathrm{bw}$ & $70.10 \pm 1.40$ & $64.86 \pm 1.40$ \\
\hline Group 7: $450 \mathrm{mg} / \mathrm{kg} / \mathrm{bw}$ & $70.40 \pm 0.72$ & $65.74 \pm 0.94$ \\
\hline
\end{tabular}

Results are expressed as mean \pm SEM $(n=5)$. "significant decrease than group 1; $\mathrm{AE}=$ Aqueous Extract of Carica papaya seed; EE = Ethanolic Extract of Carica papaya seed, $\mathrm{SEM}=$ Standard Error of Mean; $\mathrm{mg} / \mathrm{kg} / \mathrm{bw}=$ Milligram/Kilogram/Body weight; $\%=$ Percent; TBARS = Thiobarburic Acid Reactive Substances.

In Table 5, ethanolic extract showed higher activity ( $\mathrm{p}>0.05)$ when compared with Aqueous extract.

Table 5: Total Antioxidant Activity of Aqueous and Ethanolic Extracts of Carica papaya Seed using FRAP

\begin{tabular}{|c|c|c|}
\hline Treatment & $\begin{array}{c}\text { Concentration } \\
(\%) \text { AE }\end{array}$ & $\begin{array}{c}\text { Concentration } \\
(\%) \text { EE }\end{array}$ \\
\hline Group 1: Normal Control & $51.64 \pm 0.41$ & $51.64 \pm 0.41$ \\
\hline Group 2: Negative Control & $29.90 \pm 6.92^{*}$ & $29.90 \pm 6.92^{*}$ \\
\hline Group 3: Drug Control & $45.28 \pm 1.60^{\mathbf{a}}$ & $45.28 \pm 1.60^{\mathbf{a}}$ \\
\hline Group 4: $100 \mathrm{mg} / \mathrm{kg} / \mathrm{bw}$ & $24.34 \pm 7.10$ & $41.14 \pm 1.62^{\mathbf{b}}$ \\
\hline Group 5: $150 \mathrm{mg} / \mathrm{kg} / \mathrm{bw}$ & $21.90 \pm 5.13$ & $38.14 \pm 3.19^{\mathbf{b}}$ \\
\hline Group 6: 300mg/kg/bw & $16.44 \pm 4.49$ & $24.18 \pm 1.85$ \\
\hline Group 7: $450 \mathrm{mg} / \mathrm{kg} / \mathrm{bw}$ & $16.56 \pm 3.85$ & $6.56 \pm 0.21$ \\
\hline
\end{tabular}

Results are expressed as mean \pm SEM $(n=5)$. "significant decrease than group 1; 'a significant increase than group 2; bignificant increase than same groups of $\mathrm{AE} ; \mathrm{AE}=$ Aqueous Extract of Carica papaya seed; EE = Ethanolic
Extract of Carica papaya seed; SEM = Standard Error of Mean; FRAP = Ferric reducing antioxidant power; $\mathrm{mg} / \mathrm{kg} / \mathrm{bw}=$ Milligram $/$ Kilogram$/$ Body weight.

The results of Table 6 , showed group $2(56.94 \pm 3.29)$ were significant $(\mathrm{p}>0.05)$ compared with group $1(80.08 \pm 0.80)$.

Table 7: The Total Antioxidant Activity of Aqueous and Ethanolic Extracts of Carica papaya Seed using Total Proteins as an index

\begin{tabular}{|c|c|c|}
\hline Treatment & $\begin{array}{c}\text { Concentration } \\
(\mathrm{g} / \text { dl }) \text { AE }\end{array}$ & $\begin{array}{c}\text { Concentration } \\
(\mathrm{g} / \text { dl }) \text { EE }\end{array}$ \\
\hline Group 1: Normal Control & $80.08 \pm 0.80$ & $80.08 \pm 0.80$ \\
\hline Group 2: Negative Control & $56.94 \pm 3.29^{*}$ & $56.94 \pm 3.29^{*}$ \\
\hline Group 3: Drug Control & $72.12 \pm 1.02^{\mathrm{a}}$ & $72.12 \pm 1.02^{\mathrm{a}}$ \\
\hline Group 4: Conc $100 \mathrm{mg} / \mathrm{kg} / \mathrm{bw}$ & $70.12 \pm 2.09$ & $58.20 \pm 2.65$ \\
\hline Group 5: Conc $150 \mathrm{mg} / \mathrm{kg} / \mathrm{bw}$ & $65.20 \pm 2.27$ & $71.56 \pm 4.44^{\mathrm{a}}$ \\
\hline Group 6: Conc $300 \mathrm{mg} / \mathrm{kg} / \mathrm{bw}$ & $63.40 \pm 1.21$ & $51.88 \pm 2.56$ \\
\hline Group 7: Conc $450 \mathrm{mg} / \mathrm{kg} / \mathrm{bw}$ & $81.00 \pm 2.92^{\mathrm{ab}}$ & $60.36 \pm 0.75$ \\
\hline
\end{tabular}

Results are expressed as mean $\pm \operatorname{SEM}(n=5)$. "significant decrease than group 1; 'asignificant increase than group 2; ${ }^{\mathbf{a b}}$ significant increase than group 7 of $\mathrm{EE} ; \mathrm{AE}=$ Aqueous Extract of Carica papaya seed; EE = Ethanolic Extract of Carica papaya seed; SEM = Standard Error of Mean; $\mathrm{mg} / \mathrm{kg} / \mathrm{bw}=$ Milligram $/$ Kilogram $/$ Body weight; $\mathrm{g} / \mathrm{dl}=$ Gram/Decillitre.

\section{Discussion}

The phytochemicals components present in the aqueous Carica papaya seed included: saponins, tanins, phenols, alkaloids, flavonoids, terpenoids, anthraquinones, cardiac glycosides and steroids which is in agreement with the findings of Adebiyi et al (2002); Udoh and Udoh, (2005). However, the presence of Carotenoids and the absence of Cardiac glycosides, and Terpenoids were in contrast with the work of Delphin et al (2014), who reported Carotenoids was present, while Cardiac glycosides and Terpenoids were absent in the Carica papaya seed extract. This observed difference may be due to geographical location of the plant, storage or solvent used. The quantitative phytochemicals carried out revealed that phenols $20.80 \%$, flavonoids $20.40 \%$, akaloids $12.60 \%$, cardiac glycosides $18.60 \%$, tanins $9.40 \%$, steroids $9.60 \%$, terpenoids $9.20 \%$ and anthraquinones $5.80 \%$. This result has shown phenols and flavonoids $(20.80 \%$ and $20.40 \%)$ had the highest contents which agreed with the views of Delphin et al (2014). Anthraquinones and saponins $(6.40 \%$ and $5.80 \%)$ had the least compositions.

Most phytochemicals have antioxidant activity and which protect the body cells against oxidative damage and reduce the risk of developing some biochemical disorders (Amorati and Valgimigli, 2012). The Carica papaya seed decoction which contains these phytochemicals are responsible for the treatment of different ailments in many countries and also in western Nigeria (Gill, 1992). It is also used for the treatment of sickle cell anaemia (Ogunyemi et al., 2008). Flavonoids have proven ability to inhibit specific enzymes, some hormones and to scavenge free radicals (Moltiva et al., 1994). It has anti-inflammatory activity and protects gastric mucosa against a variety of ulcerogenic agents in different 


\section{International Journal of Science and Research (IJSR) \\ ISSN (Online): 2319-7064 \\ Index Copernicus Value (2013): 6.14 | Impact Factor (2014): 5.611}

animal species (Harbone and Williams, 2000). Plants containing flavonoids were found to be effective in preventing ulcer diseases because of their anti-oxidant properties (Delphin et al., 2014). The antioxidant activity of flavonoids has attracted interest because of the strong evidence that oxidation processess are involved in the mechanisms of ulcerogenesis and several other gastric disorders (La Casa et al., 2000).

The results of antioxidant activity of the Carica papaya seed extracts on indomethacin-induced peptic ulcer disease presented in Table 3 provided scientific evidence that the papaya seed extract may contain biologically active antioxidant substances. Such components like flavonoids and phenols had revealed potential anti-ulcer properties which agreed with the findings of Amorati and Valgimigli, (2012) and also with the work of Delphins et al (2014). The aqueous extract at concentration of $100 \mathrm{mg} / \mathrm{kg} / \mathrm{bw}$ produced increased effects $(p>0.05)$ when compared with the induced group. This could be mediated by any of the phytoconstituent present in the seed via anti-oxidant and free radical scavenging mechanism which agrees with the views of Amorati et al (2012). The $100 \mathrm{mg} / \mathrm{kg} / \mathrm{bw}$ of $\mathrm{AE}$ has increased $(\mathrm{p}>0.05)$ effect when compared with the standard drug control (Omeprazole). However, the standard control group has significantly increased activity $(p>0.05)$ when compared with the induced group. And when compared with 150,300 and $450 \mathrm{mg} / \mathrm{kg} / \mathrm{bw}$ of EE. The result has also shown that the $100 \mathrm{mg} / \mathrm{kg} / \mathrm{bw}$ of $\mathrm{AE}$ has significantly increased activity $(p>0.05)$ when compared with the same concentrations of EE. This could probably be attributed to the fact that ethanol is one of the noxious agent that can cause peptic ulcer disease (Falalyeyeva et al., 2010). The extract is not dose-dependent as the effect of $100 \mathrm{mg} / \mathrm{kg} / \mathrm{bw}$ of $\mathrm{AE}$ gave the highest activity.

Similar treatment as presented in Table 4 has shown the Normal group has increased activity $(p>0.05)$ when compared to the treated. However, there was no statistical difference $(\mathrm{p}>0.05)$ when the activity of the standard drug was compared with the activities of both aqueous and ethanolic extracts at all concentrations. This could probably mean that the extracts have equipotent effect as that of Omeprazole in protecting the mucosal lining against peroxidation. This agrees with the findings of Preeth et al (2010) in which the ethanolic extract of Coccinia grandis exhibited significant anti-ulcer activity with almost equipotent effect as Omeprazole.

The results presented in Table 5 has shown the standard drug has more potent effect $(p>0.05)$ when compared with the induced group and when compared with all the concentrations of AE. Standard drug has shown equipotent effect with $100 \mathrm{mg} / \mathrm{kg} / \mathrm{bw}$ of EE. This may probably be due to the mediation via antioxidant due to high concentration of phenols and flavonoids components of the extract as observed by Miller and Rice-Evans (1997); Adeneye and Benebo (2008) and also by Amorati and Valgimigli (2012).

Similarly, the total protein results presented in Table 6 showed significant increase $(\mathrm{p}>0.05)$ when the Normal control was compared to the Negative. There was significant increase in activity $(\mathrm{p}>0.05)$ when the Standard Drug control was compared with the Negative. All concentrations of both extracts have shown equipotent effect with the standard drug. This indicate their ulcer-healing property. The $450 \mathrm{mg} / \mathrm{kg} / \mathrm{bw}$ of $\mathrm{AE}$ has shown a significant increase when compared to $450 \mathrm{mg} / \mathrm{kg} / \mathrm{bw}$ of EE. This may probably be as a result of the effect of ethanol on the mucosal tissue protein which can affect it in a negative way, this is in line with the views of Aravind, (2012).

\section{Conclusion}

This study has shown that both aqueous and ethanolic extracts of Carica papaya seed has flavonoids and phenols as its more abundant antioxidant and has thus possessed anti-ulcerogenic effect. The results suggest statistically improved anti-oxidant activity of aqueous extract of Carica papaya seeds of $\mathrm{AE}$ at $100 \mathrm{mg} / \mathrm{kg} / \mathrm{bw}$ when compared with the same concentration of EE. The findings also showed that the aqueous extract of the seed has increased the total antioxidant activity when compared with that of ethanolic extract. Although the molecular mechanism of action of the bioactive components are not yet understood, but based on this study, it suggested this seed is a potential source of natural anti-oxidant that could in the near future serves as an important therapeutic agent in not only healing ulcer, but preventing its occurence.

\section{References}

[1] Amorati, R \& Valgimigli, L. (2012). Modulating of the antioxidant activity of phenols by non-covalent interactions. Organic and Biomolecular Chemistry, 10 (21), 4147-4158.

[2] Aravind, G., Debjit B., Duraivel., Harish, G. (2013). Traditional and Medicinal uses of Carica papaya. Journal of Medicinal Plants Studies, (1), 7-15.

[3] Brzozowski, T., Konturek, P. C., Konturek, S. J. (2000). Role of gastric acid secretion in progression of acute gastric erosions induced by ischemia-reperfusion into gastric ulcers. European Journal of Pharmacology, (398), 147-158.

[4] Carleton, H. (1979). Histological techniques. 4th Ed, London, Oxford University Press, Newyork, USA, Toronto, 58.

[5] Chan, F. K \& Leung, W. K. (2002). Peptic ulcer disease. Lancet, (360), 933-941.

[6] Del Valle, J \& Yamada, T. (1990). The gut as an endocrine organ. Annual Review of Medicine, (41), 447455.

[7] Delphin, D. V., Haripriya, R., Subi, S., Jothi, D and Thirumalai, R. V. (2014). Ethanolic extract of Carica papaya seed. Online.

[8] Falalyeyeva, T. M., Samonina, G. E., Beregovaya, T. V., Andreeve, L. A., Dvorshchenko, E. A. (2010). Effect of Glyprolines, PGP, GP and PG on haemostasis of gastric mucosa in rats with experimental ethanolinduced gastric ulcers. Bulletin of Experimental Biology and Medicine, 149 (6), 699-701.

[9] Fong, J. J \& Devlin, J. W. (2008). Peptic ulcer disease. In: Pharmacotherapy Principles and Practice. McGrawHill Companies, Inc, New York, 269-280. 
[10] Greenstein, B \& Greenstein, A. (2007). Gastric and duodenal ulceration and H. Pylori. In: Concise Clinical Pharmacololgy. Pharmaceutical press, 200-201.

[11] Grossman, M. (2009). Peptic ulcer: A guide for the practicing physician. American Journal of pharmaceutical Toxicology, (79), 89-93.

[12] Harbone, J. B \& Williams, C. A. (2000). Advances in flavonoid research since 1992. Phytochemistry, 55(6). 481-504.

[13] Huang, J. Q., Sridhar, S., Hunt, R. H. (2002). Role of Helicobacter pylori infection and non-steroidal antiinflammatory drugs in peptic ulcer disease: a metaanalysis. Lancet, 359:14-22.

[14] Jyotheeswaran, S., Shah, A. N., Jin, H. O. (1998). Prevalence of Helicobacter pylori in peptic ulcer patients in greater Rochester, NY: Is empirical triple therapy justified? American Journal of Gastroenterology, (93), 574.

[15] La Casa, C., Villegas, I., Alarcon de la Lastra, C., Motilva, V., Calero, M. J. M. (2000). Protective and anti-oxidant properties of rutin, a natural flavone against ethanol-induced gastric lesion. Journal of Ethanopharmacology, (71). 45-53.

[16] Luiz-Ferreira A., Cola M., Barbastefano V., HirumaLima C. A., Santos L. C., Vilegas W., Brito A. R. (2012). Anti-ulcerogenic activity of the aqueous fraction of Anacardium humile (Anacardiaceae). Journal of Medicinal Plants Research, (6), 5337-5343.

[17] Magistreni, M. J., Conti, M., Cristeni, C. (1988). Antiulcer activity of an anthrocyanidin from vaccinum myritillus. Arzneinittelforschung 38 (5), 686-690.

[18] Mogana R., Teng-Jin K., Wiart C. (2011). In vitro antimicrobial, antioxidant activities and phytochemical analysis of Canarium patentinervium miq. Malaysia Biotechnology Research, 7. (68), 673.

[19] Motilva, V., Alarcon de la Lastra, C., Martins M. J. (1994). Ulcer protecting effect of naringenin on gastric lesions induced by ethanol in rat: a role of endogenous prostaglandins. Journal of pharmacology, (46). 91-94.

[20] Ogunyemi, C. M., Elujoba, A. A. D., Urosinmi, M. A. (2008). Anti-sickling properties of carica papaya Linn. Journal of Natural Product, 55-66.

[21] Wolfe, M. M., Lichtenstein, D. R., Singh, G. (1999). Gastrointestinal toxicity of Non-Steroidal Antiinflammatory drugs. New England Journal of Medicine, (340), 1888-1899. 